Available as paper copy (order R049P, $f 20$ including postage) or microfiche (or$\operatorname{der} R 049 M, f 12.50$ including postage) at: NARD, clo Pudoc, P.O. Box 4, 6700 AA Wageningen, Netherlands (telex $45015 \mathrm{blhwg}$ ).

\title{
The in sacco degradation of crude protein and cell wall constituents in grass, alfalfa and maize silages
}

\author{
R. P. Kwakkel ${ }^{1,2}$, J. van Bruchem ${ }^{1}$, G. Hof ${ }^{2}$ and H. Boer ${ }^{2}\left({ }^{1}\right.$ Department of Animal \\ Physiology, Agricultural University, Haarweg 10, 6709 PJ Wageningen, Nether- \\ lands; ${ }^{2}$ Department of Animal Nutrition, Agricultural University, Haagsteeg 4, \\ 6708 PM Wageningen, Netherlands)
}

Received 13 January 1986; accepted 24 February 1986

\begin{abstract}
In the rumen of dairy cattle, fed on grasshay, the in sacco degradation was determined of crude protein (CP) and cell wall constituents (NDF) in grass, alfalfa (lucerne) and maize silages.

The silages were incubated for a 48 -h period. The fractional rates of degradation were estimated based on a single exponential degradation model.

Key words: crude protein, in sacco, lignin, nylon bag, rumen, solubility, NDF.
\end{abstract}

Introduction. The nutritive value of roughages for ruminants is determined by both digestibility and voluntary intake. Roughage intake is primarily limited by the capacity of the rumen, the rate of degradation in the rumen and the passage rate of undegraded feed particles from the rumen.

Of these parameters, the rate of degradation can be determined in nylon bags incubated in the rumen for various periods of time, according to the method developed by Mehrez \& Ørskov (1977).

The voluntary intake of the three silages was determined in steers (Hof et al., 1984). For grass, alfalfa (lucerne) and maize silages the daily intakes were 88.2 , 105.2 and $85.8 \mathrm{~g}$ dry matter per $\mathrm{kg}^{3 / 4}$, respectively. Of the grass and alfalfa silages, the digestion process in vivo was also studied in sheep fitted with ruminal and small intestinal cannulas (Kies et al., 1986).

In order to find an explanation for the differences in voluntary intake, the rate of degradation of cell wall constituents and crude protein was measured by the in sacco technique.

Material and methods. Samples (ca. $5 \mathrm{~g}$ dry matter) of the silages (particle length $0.5-1.5 \mathrm{~cm}$ ) were incubated in nylon bags (nylon $\mathrm{P} 41 ; 9 \mathrm{~cm} \times 18 \mathrm{~cm}$; pore size $41 \mu \mathrm{m}$ 
$\times 41 \mu \mathrm{m})$ in the rumen of two Dutch Friesian dairy cows, fed on $10 \mathrm{~kg}$ grasshay $(7.9 \% \mathrm{CP})$ and $1 \mathrm{~kg}$ mixed concentrates $(19.9 \% \mathrm{CP})$. The cows were fed twice daily at $08 \mathrm{~h} 00$ and $16 \mathrm{~h} 00$. The bags were incubated for $0,3,5,8,16,24$ and 48 hours.

After incubation, the bags were washed with cold water and subsequently freezedried. The residues were weighed, ground (1-mm sieve), pooled per incubation period and analysed for dry matter (DM), nitrogen, neutral detergent fibre (NDF), acid detergent fibre (ADF) and acid detergent lignin (ADL).

Duplicate degradation curves were determined for each silage in each cow. For DM, CP and NDF the data were fitted according to the model:

$$
Y_{t}=Y_{\mathrm{r}}+\left(Y_{\mathrm{o}}-Y_{\mathrm{s}}-Y_{\mathrm{r}}\right) \cdot \mathrm{e}^{-\alpha\left(t-t^{\prime}\right)},
$$

in which:

$Y_{t}=$ residue $(\%)$ at time $t$

$Y_{\mathrm{o}}=$ initial quantity of the component in the silage (100\%)

$Y_{\mathrm{s}}=$ soluble fraction $(\%)$

$Y_{\mathrm{r}}=$ non-degradable fraction $(\%)$

$\alpha=$ fractional rate of degradation $(\% / \mathrm{h})$

$t^{\prime} \quad=\quad$ lag-time $(\mathrm{h})$

Results and discussion. In Table 1 the composition of the three silages is given. The silages not only differed in NDF content, but also in composition of the NDF. Especially, the composition of the NDF fraction in the alfalfa silage differed considerably from that of the other silages. The alfalfa silage contained more lignin than the grass and maize silages.

In Fig. 1 the degradation of crude protein and cell wall constituents of each silage is visualized. According to the proposed degradation model, the parameters of degradation could be computed as given in Table 2. The non-degradable NDF fraction was highest in the alfalfa silage, probably caused by the high lignin content. The content of lignin, however, did not affect the fractional rate of NDF degradation, which appeared to be surprisingly low in the maize silage.

A considerable part of the crude protein fraction of the silages showed to be wa-

Table 1. Composition of the silages ( $\%$ in dry matter).

\begin{tabular}{llll}
\hline Component & Grass & Alfalfa & Maize \\
& & & \\
Organic matter & 86.3 & 90.1 & 95.7 \\
Crude protein & 12.9 & 19.1 & 8.9 \\
NDF & 60.2 & 48.8 & 44.9 \\
cellulose & $31.9(53)^{2}$ & $32.1(66)$ & $22.5(50)$ \\
hemicellulose & $24.6(41)$ & $6.9(14)$ & $19.6(44)$ \\
lignin & $3.7(6)$ & $9.8(20)$ & $2.8(6)$ \\
\hline
\end{tabular}

${ }^{1} \mathrm{~N} \% \times 6.25$

${ }^{2}$ As a percentage of the NDF fraction. 

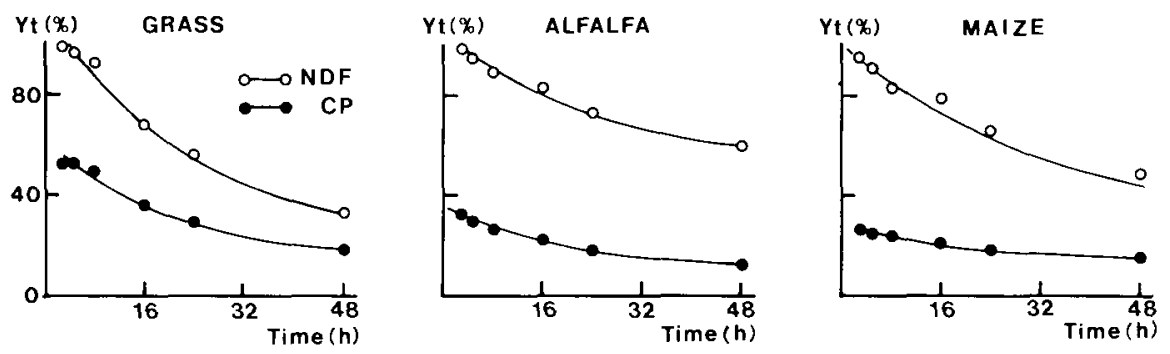

Fig. 1. The in sacco degradation of crude protein $(\mathrm{CP},-)$ and cell wall constituents $(\mathrm{NDF}, \mathrm{O})$ in the silages. Per silage component $Y_{\mathrm{o}}=100 \%$.

ter-soluble. The rate of degradation of the non-soluble, but degradable fraction was not closely related to the content and composition of the NDF fraction. This can partly be explained by crude protein and cell wall constituents residing in different plant structures.

No close relationship could be demonstrated between the degradation of the cell wall constituents cellulose, hemicellulose and lignin.

The extent of degradation of roughage cell wall constituents, during the time interval the roughage particles are retained in the rumen, is believed to determine partly voluntary intake. The extent of degradation of the alfalfa cell walls was lower than that of the other silages, mainly caused by the higher non-degradable fraction. Nevertheless, the voluntary intake of the alfalfa silage in steers was highest (Hof et al., 1984).

It seems therefore that the voluntary intake of roughages cannot be explained by the content, composition and degradation of the cell wall constituents only. Probably the physical structure is involved as well.

Table 2. Parameters of degradation of the silages.

Grass Alfalfa $\quad$ Maize $\quad \mathrm{SEM}^{1}$

Crude protein

$\begin{array}{lrrrr}\alpha(\% / \mathrm{h}) & 5.2 & 5.0 & 6.3 & 0.8 \\ Y_{\mathrm{s}}(\%) & 44.4 & 64.6 & 72.5 & 1.2 \\ Y_{\mathrm{r}}(\%) & 13.4 & 9.7 & 14.7 & 1.0 \\ t^{\prime}(\mathrm{h}) & 3.5 & 0.6 & 2.6 & 1.0\end{array}$

Cell wall constituents

$\begin{array}{lcccc}a(\% / \mathrm{h}) & 4.3 & 4.0 & 2.8 & 0.4 \\ Y_{\mathrm{s}}(\%) & - & - & - & - \\ Y_{\mathrm{\tau}}(\%) & 20.4 & 52.1 & 24.6 & 2.5 \\ t^{\prime}(\mathrm{h}) & 4.4 & 3.0 & 0.6 & 0.5\end{array}$

${ }^{1}$ Standard error of the mean. 


\title{
References
}

Hof, G., H. Boer \& P. J. Lenaers, 1984. Celwanden, parameters voor de ruwvoederopname? Landbouwkundig Tijdschrift $96(6): 25-28$.

Kies, A. K., J. van Bruchem, G. Hof \& H. Boer, 1986. The digestion of grass and alfalfa silages in the forestomachs and intestines of sheep. Netherlands Journal of Agricultural Science 34: 119-122.

Mehrez, A. Z. \& E. R. Ørskov, 1977. A study of the artificial fibre bag technique for determining the digestibility of feeds in the rumen. Journal of Agricultural Science, Cambridge 88: 645-650.

This synopsis is based on an undergraduate thesis entitled 'De in sacco afbraak van een gras-, luzerne- en snijmaissilage' by R. P. Kwakkel, Department of Animal Physiology, Agricultural University, Wageningen, 1985. 84 pp., 12 figs., 19 tables, 58 refs., 13 appendices. Dutch.

Available as paper copy (order R050P, $f 30$ including postage) or microfiche (order R050M, f 12.50 including postage) at: NARD, c/o Pudoc, P.O. Box 4, 6700 AA Wageningen, Netherlands (telex 45015 blhwg).

\section{The digestion of grass and alfalfa silages in the forestomachs and intestines of sheep}

A. K. Kies ${ }^{1,2}$, J. van Bruchem ${ }^{1}$, G. Hof ${ }^{2}$ and H. Boer ${ }^{2}\left({ }^{1}\right.$ Department of Animal Physiology, Agricultural University, Haarweg 10, 6709 PJ Wageningen, Netherlands; ${ }^{2}$ Department of Animal Nutrition, Agricultural University, Haagsteeg 4, 6708 PM Wageningen, Netherlands)

Received 13 January 1986; accepted 24 February 1986

\begin{abstract}
In wethers fitted with cannulas in the dorsal rumen sac and the small intestine, the digestion process of cell wall constituents and protein was followed of a grass and alfalfa (lucerne) silage, containing on a dry matter basis $12.9 \%$ crude protein (CP), $60.2 \%$ neutral detergent fibre (NDF) and $19.1 \% \mathrm{CP}, 48.8 \% \mathrm{NDF}$, respectively. Intake was 46.5 and $49.0 \mathrm{~g} \mathrm{DM} \mathrm{kg}^{-3 / 4} \mathrm{day}^{-1}$, respectively. In the reticulorumen the retention time of the fluid phase and particulate phase, with CoEDTA and CrNDF as a marker respectively, were estimated. The digestion of the cell wall constituents was investigated in the forestomachs and in the hind gut. Both protein degradation and microbial protein synthesis were estimated in the forestomachs and subsequently the digestion of protein in the intestines.

Key words: cell wall constituents, cellulose, hemicellulose, lignin, protein degradation, amino acids, retention time, microbial protein synthesis.
\end{abstract}

Introduction. The voluntary intake of roughages in ruminants is assumed to be restricted by the capacity of the reticulorumen. Hence the extent of degradation and 